
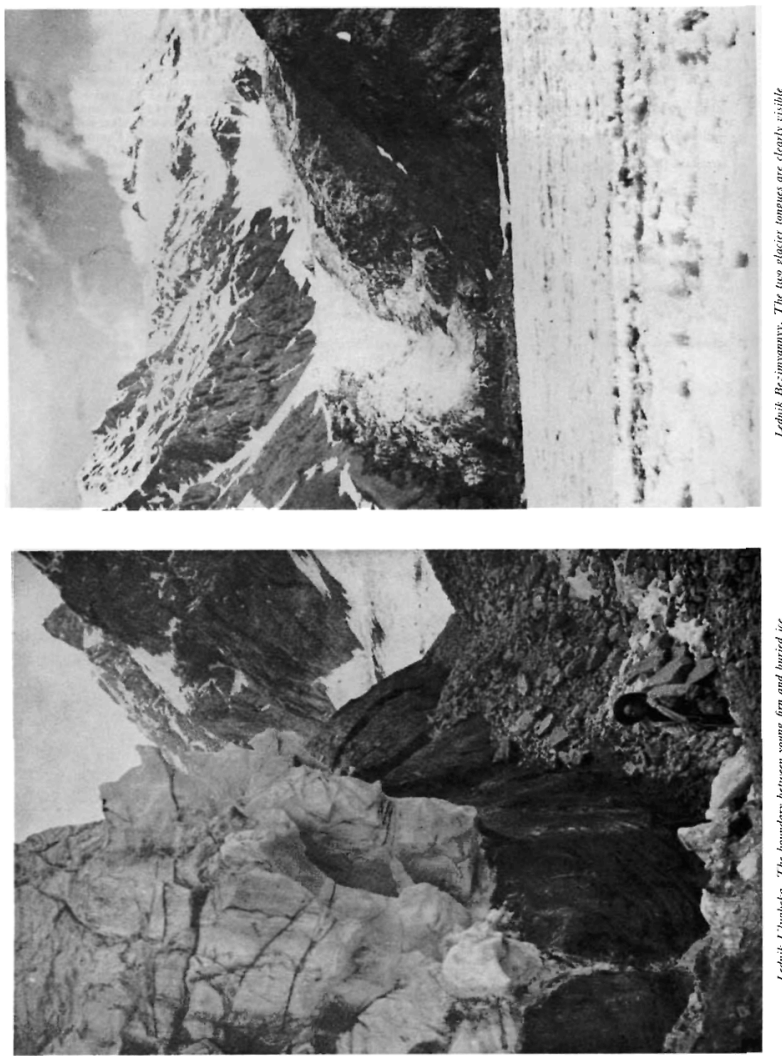


\title{
ON THE ADVANCE OF GERTAIN GLACIERS OF THE NORTH-WESTERN PAMIRS
}

\author{
By V. F. Suslov \\ (Scientific Secretary of the Department of Technical Sciences, \\ Academy of Sciences of the Uzbek S.S.R.)
}

THE glaciological investigations carried out under the I.G.Y. programme by the expedition of the Academy of Sciences of the Uzbek S.S.R. to the Pamirs permit evaluation of the state of one of the largest centres of contemporary mountain glaciation in the following ranges of mountains: Akademii Nauk, Yazgulem, Yuzhnoy Gruppy Fedchenko, Severnyy Tanymas and Kyz-Kurgan, in all an area of more than a thousand square kilometres.

It has been established that the great majority of glaciers of the Lednik Fedchenko basin exhibit a tendency towards reduction of their area. At the present time many large tributary glaciers have lost their connection with the main body of Lednik Fedchenko and have considerably diminished in size. This was particularly marked in the case of the following glaciers: Malyy Tanymas, Alert and others.

We may recall that in 1928 in the region of Lednik Fedchenko the large and complex Soviet-German expedition worked. This was organized by the Academy of Sciences of the U.S.S.R., to which fell the honour of filling in the last gap in the map of this part of the Pamirs which is so difficult of access.* As a result of the work of the expedition the first detailed map of the region was compiled, and when this is compared with the present position of the glaciers, exceptionally interesting material is obtained on their condition and evolution over a 30-year period. The analysis of this material shows that a significant retreat of the glaciers took place in the period between 1928 and 1946 and continues quite intensively at the present time.

Against this background of the general diminution of the glacierized area one notices particularly the glaciers Ulugbeka, Kalinina, and Bezimyannyy, which show a clear advance. (See photographs on p. 762 .)

Lednik Ulugbeka, which is in the mountain system of Khrebet Kyz-Kurgan, at present has no link with Lednik Fedchenko and is separated from it by a distance of $2.5 \mathrm{~km}$. The part of the valley which has been freed of ice shows fresh signs of the recent presence of the glacier in the shape of large, well-polished boulders, of various accretions of lateral moraine and of glacial debris buried under a thick layer of moraine. However, the process of retreat has ceased here and one now observes the energetic movement of the glacier in the reverse direction-down the valley. Convincing evidence of this is found in the tongue of Lednik Ulugbeka, which is at the height of $4,130 \mathrm{~m}$. and in plan has a characteristic convex shape. The vertical ice wall of its snout rises more than $30 \mathrm{~m}$. above the valley floor and exhibits concave ice stratification. The surface of the glacier tongue is almost entirely free of moraine and is broken up by a great many crevasses which are due to the strong movement of the ice. However, the most significant evidence of the renewal of activity of Lednik Ulugbeka is the fact that young "firn ice" has crept over the earlier ice which has been made dirty by morainic material. A natural exposure along the left side of the glacier permits one to follow this contact, which is well marked by a layer of moraine, for a distance of about $2 \mathrm{~km}$. The buried layer of darker ice wedges out at a distance of $300 \mathrm{~m}$. from the snout of the glacier. All this demonstrates that Lednik Ulugbeka, which has in the recent past been through a

* German participation in this expedition was organized by the Notgemeinschaft der Deutschen Wissenschaft in Berlin. The most important scientific results are contained in Richard Finsterwalder, Geodetische, topographische und glaziologische Ergebnisse, Bd. I and Bd. 2, Berlin, Verlag Dietrich Reimer, I932. The second volume contains two maps of the Fedchenko-Tanymas district with photogrammetric contour lines at 50 metre intervals.

These maps are also to be found in the Zeitschrift für Gletscherkunde, Bd. 23, 1935. This also contains an article by Karl Wien-Die Gletschergebiete der Pamire und Westturkestans (p. 36-57). The maps are held in the library of the British Glaciological Socicty. The names are mostly German and have since been altered to Russian. Ed. 
phase of retreat, is now actively advancing and has moved forward not less than $300 \mathrm{~m}$. If one supposes that the adjacent "firn ice" is also not standing still but is moving together with the rest of the glacier, then its movement is in fact greater.

Another example of a renewal of glacial activity in this region is Lednik Kalinina, a left tributary of Lednik Bivachnyy. The glacier is $8 \mathrm{~km}$. long, $400 \mathrm{~m}$. wide, and is covered with a continuous layer of moraine. At the lower end of Lednik Kalinina there is a sharp break in the longitudinal profile and an ice fall has been formed, entirely blocking the valley. Investigations showed that until recently the glacier was diminishing in area. Evidence of this is the presence of large walls of lateral moraine deposited by the glacier on either side of the valley and bearing witness to its former higher level. However, at present there are clear signs of renewed activity of the glacier. This is seen in the flow of the broad stream of "firn ice" at the left-hand edge of the valley through the ice fall. Evidently abundance of atmospheric precipitation has here created the right conditions for formation of a second layer of the glacier, moving faster than the lower layer. The stream of ice is moving over the tongue of the glacier, which is covered with moraine, and has reached a distance of $300 \mathrm{~m}$. from the bottom of the ice fall.

The advance of Lednik Bezimyannyy is especially striking. This glacier is situated on the southern slope of Khrebet Kyz-Kurgan and flows into the basin of Lednik Fedchenko. It is $2 \mathrm{~km}$. long and $250 \mathrm{~m}$. wide. Observations of this glacier carried out from 1956 to I959 confirm that a noticeable growth in the glacier tongue took place in 1958. At present the glacier is continuing to advance and will evidently soon join Lednik Fedchenko. It is characteristic that the movement of the ice mass down the valley flows partially over the remains of the former glacier and also flows round it on the right-hand side of the valley. As a result of this two glacier tongues have been formed in the valley, and one of them has moved 300 to $35^{\circ} \mathrm{m}$. beyond the other.

Finally, mention must be made of the birth of a new glacier, a fact established by us in the upper reaches of the Tanymas valley. After the winter of i957-58, during which much snow fell, a hanging glacier formed on the left slope of the valley in line with Lednik Astronomicheskiy at a height of $4,400 \mathrm{~m}$. This glacier has reached a length of $350-400 \mathrm{~m}$. and has a well defined area of alimentation. In 1959 the glacier did not melt and it continues to exist, preserving its original features.

All the cases mentioned of glacier advance, with the exception of the last one, relate to the basin of Lednik Fedchenko and are local in character. This bears witness to the fact that conditions obtaining in the north-western part of the Pamirs are very varied and cannot be considered as a whole.

On the other hand climatic observations, which have been made here for only a very small number of years, do not permit any convincing explanation of the causes of the fluctuations mentioned. It can only be supposed that one of the most significant features in these processes was the abundance of atmospheric deposits during the winter of 1957-58. The mean precipitation for the 3 winter months during the 10 years $1934-45$ was $254 \mathrm{~mm}$. in the central part of Lednik Fedchenko. During the winter of $1957-5^{8}$ the mean precipitation reached $407 \mathrm{~mm}$.

Taking into account the fact that almost all the glaciers mentioned have a southerly exposure (with the exception of Lednik Ulugbeka), then with the prevailing southerly and south-westerly winds the basins of these glaciers should retain a very large quantity of solid precipitation.

Another significant circumstance, in our opinion, is the considerable altitude of the glaciers (in all cases around 4,000 and more metres), and this creates favourable conditions for their rapid development and growth.

MS. received 29.7 anuary 1960 